\title{
EUSÉBIO DE CESAREIA E A FORMATAÇÃO DO CRISTIANISMO COMO BASE IDEOLÓGICA PARA O PODER IMPERIAL NO SÉCULO IV
}

\author{
Andréia Rosin Caprino ${ }^{1}$
}

Resumo: Flávio Valério Constantino (306-337) estava inserido em um espaço em que a base ideológica do poder estava em transformação, devido às reestruturações político-institucionais do mundo romano, bem como às diversas ideias que coexistiam e influenciavam o seu governo. Eusébio de Cesareia (260/65-339/40), bispo cristão desta cidade desde aproximadamente o ano de 313 até a sua morte, tornou-se principalmente conhecido por ter iniciado dois gêneros narrativos: a Crônica cristã e a História da Igreja. Este artigo é dedicado especialmente à História Eclesiástica, a narrativa de Eusébio que se inicia com a vinda de Jesus Cristo como homem ao mundo e termina com a derrota de Licínio por Constantino, em 324. Temos por intuito observar e explicar como foram construídos argumentos na História Eclesiástica apontando para a legitimação do poder imperial romano, em um momento da Antiguidade Tardia de instabilidade e desestruturação política.

1 Andréia Rosin Caprino é graduanda do curso de História - Bacharelado e Licenciatura - da Universidade Federal do Paraná (UFPR). Sob orientação do Prof. Dr. Renan Frighetto, desenvolve sua pesquisa vinculada ao Programa Institucional de Bolsa de Iniciação Científica (PIBIC), financiado pelo CNPq. E-mail: andreiarosincaprino@gmail.com 
Revista Vernáculo, $n^{\circ} 28,2^{\circ}$ sem/2011

Palavras-chave: Eusébio de Cesareia, História Eclesiástica, cristianismo, legitimação imperial.

\begin{abstract}
Flavius Valerius Constantine (306-337) was inserted into a space in which the ideological basis of power was changing, and this was because of the political and institutional restructuring of the Roman world, as well as the various ideas that coexisted and influenced his government. Eusebius of Caesarea (260/65-339/40), Christian bishop of this city since about the year 313 until his death, became mostly known for having initiated two narrative genres: the Chronicon and the Church History. This article is dedicated especially to the Ecclesiastical History, the narrative of Eusebius that begins with the coming of Jesus Christ as a man to the world and ends with the defeat of Licinius by Constantine in 324. We aim to observe and explain how arguments in the Ecclesiastical History were built, pointing to the legitimation of Roman imperial power, in a time of the Late Antiquity of political instability and disintegration.
\end{abstract}

Keywords: Eusebius of Caesarea, Ecclesiastical History, Christianity, imperial legitimation. 


\section{A VIDA DE EUSÉBIO DE CESAREIA}

Eusébio de Cesareia talvez seja muito mais conhecido entre os teólogos do que entre os historiadores. Isso se deve ao fato de ter se constituído em um dos grandes nomes vinculados à política religiosa de Constantino o Grande, difundido por muito tempo, e tendo repercussões até os dias atuais, como o "Imperador cristão". ${ }^{2}$ Nascido na região da Palestina entre os anos 260 e 265, vive na Cesareia marítima desde jovem, local em que recebe vasta formação cultural através da biblioteca desta cidade, fundada por Orígenes e mantida por Pânfilo. Este último foi seu mestre e amigo, e os anos de convívio e aprendizagem renderam a Eusébio a outra designação pela qual é conhecido - Eusebius Pamphilus. Não há informações sobre sua procedência familiar; a fonte mais antiga que relata a vida do erudito foi escrita por Acácio, seu sucessor no episcopado, porém nunca foi encontrada ${ }^{3}$.

${ }^{2}$ DANIÉLOU, Jean e MARROU, Henri, em Nova História da Igreja (p.253), afirmam: "A fronteira entre o temporal e o espiritual, o profano e o sagrado, não se estabelece entre as instituições da Igreja e as do Império: insinua-se por vezes, de forma dramática, no interior mesmo da personalidade tão complexa do imperador cristão...".

${ }^{3}$ Quem relata tal perda é Sozomeno, em sua História Eclesiástica, escrita na primeira metade do século V. 
Durante a perseguição aos cristãos desencadeada por Diocleciano a partir de 303, na qual Pânfilo foi encarcerado e morto, Eusébio refugiou-se em Tiro e depois no Egito, onde acabou prisioneiro. Com o edito de tolerância de 311 promulgado por Galério, retornou à Palestina e tornou-se bispo de Cesareia por volta do ano de 313. O bispo iniciou a redação de suas obras, de caráter apologético, exegético, dogmático e histórico, já antes da elevação a tal posição.

Participou de diversos concílios (Antioquia, Niceia, Tiro, Jerusalém, entre outros), teve contato com Constantino em algumas ocasiões, como na comemoração dos trinta anos de seu governo, e escreveu obras até o fim da vida, em 339/340, na própria Cesareia, dois anos após a morte do governante, ao qual dirigiu algumas de suas composições literárias. A principal delas é a Vida de Constantino (Vita Constantini), uma de suas últimas obras, não revisada e publicada por Acácio; antes disso, redigiu Em Louvor de Constantino (De Laudibus Constantini), discurso proclamado em 335 que festeja a Tricenália do governo constantiniano e contém uma introdução apologética ao cristianismo; e o trabalho ao qual nos ocupamos particularmente nesta pesquisa: a História Eclesiástica (Historia Ecclesiastica), publicada com seu conteúdo completo por volta de 325 . 
Embora a História Eclesiástica não tenha sido escrita diretamente a Constantino, é relatada em seu final a vitória do imperator, associado por Eusébio ao Deus cristão, sobre o rival Licínio, em 324. É esta a obra pela qual o autor tornou-se mais conhecido: reúne documentos dos três primeiros séculos da Igreja cristã e relata seus principais acontecimentos, no contexto de liberalização e oficialização gradativa do cristianismo como uma religião associada ao poder político romano, representado neste momento pela figura máxima de Constantino.

Além de ter elaborado a primeira Crônica cristã (na qual tenta provar a antiguidade do cristianismo), Eusébio ficou conhecido como o "pai da história eclesiástica", por ter sido o pioneiro na tarefa de reunir fatos cristãos em forma de uma descrição histórica, servindo de modelo para vários escritores ao longo dos séculos seguintes, e recebendo especial atenção dos estudiosos da Bíblia e defensores e apologistas desta religião. Nosso estudo é centrado não somente na consideração desse personagem como um homem de seu tempo que, incomodado pelos acontecimentos e conflitos religiosos do conturbado século IV, produz trabalhos que visam à justificação do cristianismo como uma religião autêntica, como também e, principalmente, um historiógrafo cristão atrelado ao poder político romano. 
A constatação acima nos leva a refletir e questionar a escrita da obra: por que Eusébio construiu uma história eclesiástica? Qual era sua intenção ao fazê-la? Quais as influências que recebeu? Qual a implicação da obra para o governo romano centrado na figura de Constantino? Essas são algumas problemáticas geradas pelas características de interação e renovação do período tardo-antigo ${ }^{4}$ que embasam o presente estudo. Buscamos agora observar o papel do bispo cristão dentro do cenário imperial romano, em um contexto de busca por afirmação do poder, como resultado da desestruturação e fragmentação política existente desde o século III com a denominada Anarquia Militar.

Dessa maneira, nosso estudo é focado na análise da construção da legitimação do poder imperial através do elemento cristão, sendo este amplamente defendido por Eusébio na História Eclesiástica, em um momento de instabilidade político-institucional no qual Constantino almeja à consolidação e ampliação de sua autoridade e base de poder.

\footnotetext{
4 Segundo Renan Frighetto, em A longa Antiguidade Tardia: problemas e possibilidades de um conceito historiográfico (p.112), a Antiguidade Tardia, portadora de representações em movimento, advindas do mundo clássico greco-romano e reformuladas para responderem aos anseios do seu tempo, deve ser entendida como "uma etapa de transformações no ambiente político, ideológico, institucional e cultural que tiveram uma notória influência sobre os desígnios do mundo imperial romano e de suas herdeiras mais diretas, as monarquias romano-bárbaras".
} 
Neste ínterim, a cidade portuária de Cesareia $^{5}$ recebe especial atenção em primeiro lugar por sua localização geográfica - ponto de encontro de vários povos e culturas - e em segundo lugar, e como consequência, por abrigar no seu seio ideias e filosofias que apresentam novidades ligadas à tradição, como é o caso da relação do cristianismo com as tradições hebraica e pagã, expressa na obra citada.

Na perspectiva de forte união entre política e religião no século IV, vários autores abordam a relação do poder imperial com o poder divino, que ganha nesse período maior contorno cristão. A nível teórico, intelectuais da época - Eusébio é um nome de destaque - formulam um caráter sacralizado do imperator associando-o ao cristianismo. Ao falar das querelas religiosas no tempo de Constantino, Henri Marrou e Jean Daniélou, em "Nova História da Igreja", afirmam que o governante não permaneceu estranho às realidades espirituais, assim como os súditos cristãos reclamavam sua intervenção nos assuntos religiosos. " $O$ interesse que o imperador volta às questões religiosas é muito mais direto, mais profundo; também ele participa do espírito da nova

\footnotetext{
5 Joseph Patrich, no capítulo "Caesarea in the time of Eusebius", in: Reconsidering Eusebius (p.1-5) nos informa que sob o governo romano Cesareia transformou-se num centro de sabedoria grega (filosofia, gramática, retórica) e numa escola de lei romana. A cultura helenística ali presente foi elogiada já no primeiro século da era cristã em uma carta endereçada ao conselho da cidade, pelo filósofo Apolônio de Tyana.
} 
religiosidade". ${ }^{6}$ Assim, sob sua autoridade o mundo romano é unificado e o poder imperial aparece como imagem terrestre da monarquia divina.

Cristina Godoy e Josep Vilella, em "Antiguedad y Cristianismo Monografias históricas sobre la Antiguedad Tardia", mencionam que com a Paz da Igreja e o advento de Constantino, a relação entre a Igreja e o Estado mudou radicalmente. A filosofia eclesiástica lhe outorgou a missão de promover o bem-estar espiritual e temporal dos homens dentro do Império; responsável por isso foi a composição da teologia política do cristianismo de Eusébio de Cesareia. Conectando o Reino de Deus ao Império-Cristão, Constantino poderia legitimar seu poder em uma origem divino-cristã, que daria certa divindade a sua pessoa e asseguraria poder absoluto, já que o monoteísmo comportaria a monarquia - "o governo de um só".

Segundo Paul Veyne em seu livro "Quando o nosso mundo se tornou cristão", a partir da conversão sincera e crença no seu papel de condutor da humanidade, tal como Jesus o fora, Constantino instalou a Igreja no Império e deu ao governo central uma função nova, a de ajudar a verdadeira religião.

${ }^{6}$ DANIÉLOU, Jean e MARROU, Henri. “A Igreja na primeira metade do quarto século”, in: Nova História da Igreja. Petrópolis: Vozes, 1973, v. I p.253.

${ }^{7}$ GODOY, C.; VILELLA, J. De la fides ghotica a la ortodoxia nicena: inicio de la teologia política visigótica, in: Antigüedad y Cristianismo - Monografias históricas sobre la Antigüedad Tardia. Murcia: 1986, p. 117-118. 
Não, Constantino não se dirigiu ao Deus cristão por superstição, porque teria imaginado, não se sabe porquê, que, melhor do que outros deuses, o dos cristãos lhe concederia a vitória; não, o crisma pintado nos escudos dos seus soldados não era um sinal mágico, como por vezes se afirmou, mas uma profissão de fé: a vitória de Constantino seria a do verdadeiro Deus [...] Constantino converteu-se porque acreditou em Deus e na Redenção, foi esse o seu ponto de partida, e esta fé implicava aos seus olhos que a Providência preparava a humanidade para o caminho da salvação; e que, por conseguinte, Deus daria a vitória ao seu campeão... ${ }^{8}$

Encontramos posição semelhante em J.M .Blázquez no livro "Cristianismo primitivo e religiones mistéricas", quando afirma, a partir da História Eclesiástica, que Constantino é um imperador e varão piedoso, filho de um pai piedoso e prudentíssimo em tudo. Combateu aos ímpios tiranos aliado a Deus de maneira extraordinária, fazendo Maxêncio ser derrotado, assim como ocorreu com Licínio alguns anos depois.

$\mathrm{Na}$ interpretação de Andréia Cristina Lopes Frazão a respeito da fonte citada, Jesus veio ao mundo durante o reinado de Augusto por

\footnotetext{
${ }^{8}$ VEYNE, Paul, Quando o nosso mundo se tornou cristão. Lisboa: Edições Texto \& Grafia, 2007. p.57-58).

${ }^{9}$ BLÁZQUEZ, J.M. La política imperial sobre los cristianos. De la Tetrarquía a Teodosio, in: Cristianismo primitivo y religiones mistéricas. Madrid: Cátedra, 2007, p.272.
} 
dois motivos: primeiro porque os povos estavam reunidos sob governo romano, e segundo porque Deus preparou gradativamente os homens para receberem a mensagem divina naquele momento.

Com a vinda de Cristo, surge a Igreja Cristã. Segundo Eusébio o cristianismo era, aparentemente, novo, porém, não o era; já que era o cumprimento das profecias do Antigo Testamento. Portanto, a história da comunidade cristã surge intimamente ligada à História do Império Romano. Pois a Igreja cristã traz a unidade da fé para completar a obra da unidade política promovida pelo Império. Desta forma, o universalismo presente na crônica e na História Eclesiástica forma um grande sistema divino no qual a Igreja e o Império são, apenas, capítulos desta História Universal dirigida por Deus. ${ }^{10}$

Além do trecho acima demonstrar o que mencionamos a respeito da interação entre política e religião, aponta também para o caráter de continuidade do cristianismo em relação à tradição hebraica. Seguindo nesse raciocínio de permanências e transformações, podemos afirmar que a religião cristã, além da base bíblica hebraica, tem fundamentos pagãos, como Renan Frighetto defende ao falar sobre a formulação por escritores cristãos, como Lactâncio e Eusébio, do caráter sagrado do governante (Imperator Sacratissimus) em consonância com a sagração

\footnotetext{
10 FRAZÃO, Andréia Cristina Lopes. O nascimento da Historiografia cristã no IV século. Calíope. Presença Clássica, Rio de Janeiro, n. 9, p. 1993, p.86
} 
dada a dirigentes pagãos, como por exemplo, Maximiano, que recebera o título de Herculius.

O sea, se nota que los autores cristianos mantuvieran ciertos vínculos com La tradición anterior no quizás los panegeristas paganos recibieron influjos Del pensamiento cristiano [...] Em este caso más que imposición de ideas notamos, esto si, uma interrelación cultural intensa y de difícil ubicación. Em líneas generales parece indudable afirmar la fuerte tradición helenística basada, sobretodo, em lãs religiones mistericas muy populares em Roma desde mediados Del siglo II, especialmente el culto a Mitra, que conducían al "monoteísmo pagano" y La valorización de La devoción, por parte del poder imperial, del Sol Invictus...

Gilvan Ventura da Silva e Norma Musco Mendes ${ }^{12}$, em "Repensando o Império Romano - perspectiva socioeconômica, política e cultural", apresentam a ideia da criação de uma basileia dentro do cenário político romano como consequência da crise do século III, na qual os imperadores se sucediam no poder constantemente e estavam rodeados de golpes e contragolpes gerando fragilidade governamental

\footnotetext{
${ }^{11}$ FRIGHETTO, Renan.. Algunas consideraciones sobre las construcciones teóricas de la centralización del poder político en la Antigüedad Tardia: cristianismo, tradición y poder imperial, In: História: Entre el pesimismo y la esperanza. Viñadel Mar: Altazor, 2007.

${ }^{12}$ SILVA, Gilvan Ventura da; MENDES, Norma Musco. Diocleciano e Constantino: a construção do DOMINATO, in: Repensando o Império Romano - Perspectiva socioeconômica, política e cultural. Vitória: Edufes, 2006.
} 
(Anarquia Militar). Ocorre, então, crescente tendência à divinização do imperador antes mesmo de sua morte: isso pode ser notado já com Aureliano neste mesmo século, que em suas emissões monetárias se faz proclamar deus et dominus natus e é descrito como um deus vivo reinando sobre a terra, ou seja, reina com a delegação direta da divindade.

Desse modo, o imperador tem a sua natureza transmutada, equiparando-se às próprias divindades, como podemos constatar nos títulos de Iovius e Herculius revestidos por Diocleciano e Maximiano. Segundo os pagãos, a assistência deferida pelos deuses aos imperadores se exprimia pelas virtudes demonstradas por estes últimos: pietas, felicitas, virtus, victoria, as quais garantiriam a reprodução sobre a terra da ordem divina. ${ }^{13}$

Para os autores, a construção dessa teologia política recebe com Constantino um forte impulso advindo da contribuição cristã, particularmente através das reflexões de Eusébio de Cesareia contidas na Vida de Constantino (Vita Constantini) e Em Louvor de Constantino (De Laudibus Constantini). A respeito desta última obra, Gilvan e

\footnotetext{
${ }^{13}$ SILVA, Gilvan Ventura da; MENDES, Norma Musco. Diocleciano e Constantino: a construção do DOMINATO, in: Repensando o Império Romano - Perspectiva socioeconômica, política e cultural. Vitória: Edufes, 2006.
} 
Miguel Marvila ${ }^{14}$ defendem que Eusébio, por influência de Orígenes e Pânfilo, estava já sensível à ideia de um autor do século II, chamado Melito de Sárdis, que correlacionava estritamente a Pax Romana e o advento de Cristo. Eusébio, após 312, refletiu, pois, sobre um assunto praticamente negligenciado pelos escritores pagãos, conforme Gilvan e Norma Mendes apontam: o caráter sagrado da monarquia romana; tornando-se "o principal difusor de uma representação particular da monarquia romana, que costumamos designar como basileia, a realeza sagrada helenístico-cristã que se perpetuará em Bizâncio após a desagregação do Império Romano do Ocidente."

Arnaldo Momigliano ${ }^{15}$ afirma que Eusébio almeja demonstrar a continuidade entre os pensamentos pagão e cristão na obra Preparação Evangélica (Preparatio Evangelica) e pretende preservar a herança cultural pagã da nova ordem cristã, através da utilização da tradição pagã em sua história eclesiástica; o que pode ser notado no próprio caráter da obra ao substituir, por exemplo, as batalhas políticas por querelas religiosas.

\footnotetext{
${ }^{14}$ SILVA, G.V; MARVILA, M. De Laudibus Constantini: o discurso de Eusébio de Cesareia sobre a realeza. ES: Dimensões, 2006.

${ }^{15}$ MOMIGLIANO, Arnaldo. As origens da historiografia eclesiástica, in: As raízes clássicas da historiografia moderna. Bauru: Edusc, 2004, p.195-198.
} 


\section{A OBRA HISTÓRIA ECLESIÁSTICA}

A História Eclesiástica (Ekklesiastikè historía) possui dez livros que relatam fatos desde a vinda de Jesus Cristo ao mundo até a vitória de Constantino sobre Licínio em 324, incluindo a sucessão de bispos nas sedes episcopais, o apontamento de heresias, as perseguições aos cristãos e as tribulações ocorridas sobre os judeus. Para a atual investigação científica observamos somente o prefácio da obra (livro primeiro) e o último livro (décimo). Iniciada a redação na última década do século III, ganhou sua forma completa e definitiva pouco depois de 324. Conjectura-se que a H.E tenha sido traduzida já no século IV ao siríaco e mais tarde ao armênio. Em 402, Rufino fez uma versão latina estendendo a escrita da obra até o ano de 395. Além das três mencionadas, foi feita uma versão copta.

Vários autores já discutiram a respeito das datas e etapas das publicações da fonte em questão: Eduard Schwartz, Richard Laqueur, H.J. Lawlor, Timothy D. Barnes, Vincent Twomey são alguns deles. ${ }^{16}$ Seguindo Schwartz, podemos afirmar que foram feitas quatro edições

\footnotetext{
${ }^{16}$ Discussões detalhadas sobre as edições podem ser encontradas em F. Winkelmann, "Historiography in the Age of Constantine", in Greek and Roma nhistoriography in Late Antiquity, G. Marasco (ed.). Boston: Brill, 2003, p.3-10; e em EUSEBIUS, "Introduction", in Ecclesiastical History. Books 1-5.Harvard University Press, 1926, p.19-27.
} 
da História Eclesiástica: a primeira em oito livros incluindo Mártires da Palestina entre os anos de 312 e 313; a segunda contando com o livro nove e parte do dez em 315; a terceira edição que incluiu acontecimentos ao livro dez, publicada em 317; e a quarta, que adicionou ao último livro a derrota de Licínio, e foi publicada após 323.

Para nossa pesquisa, utilizamos três versões: uma da Loeb Classical Library, que apresenta os textos em grego e inglês, traduzida por Kirsopp Lake; outra versão em italiano, da Città Nuova Editrice, com a tradução de Salvatore Borzì, Franzo Migliore e Giovanni Lo Castro; e uma terceira, da editora Paulus, coleção Patrística.

Segundo Eustaquio Salor, ${ }^{17}$ as histórias eclesiásticas constituemse em um subgênero historiográfico cristão em que são retratadas as histórias das principais sedes episcopais cristãs desde seu início até o momento em que se escreve, tendo como abordagem central a sucessão de bispos dessas sedes. Possuem enorme importância dentro da historiografia cristã durante os séculos IV, V e VI, ao procurarem responder a necessidades apologéticas e doutrinárias. Sua relevância reside também no conteúdo: como qualquer história de um povo ou de

\footnotetext{
${ }^{17}$ SALOR, Eustaquio Sánchez. Historiografía latino-cristiana: princípios, contenido, forma. Roma: L'erma di Bretschneider, 2006, p.38-43.
} 
um grupo, as histórias eclesiásticas retratam histórias da Igreja a partir do momento em que esta adquire consciência de si e de seu papel na história; os próprios membros buscam compor a história da Igreja, da qual fazem parte.

Eusébio inicia a História Eclesiástica abordando a questão da divindade e humanidade de Jesus Cristo, e termina o relato ao mencionar a vitória de Constantino e concomitante derrota de seu rival Licínio. Logo no começo do livro I, aponta os temas que serão trabalhados:

A sucessão dos santos Apóstolos [...]; a enumeração de tantos e tão importantes eventos no curso da História Eclesiástica; quantos nela mencionados presidiram e governaram com destaque as dioceses mais ilustres; em cada geração, quantos foram deputados para ministrar a palavra divina oralmente ou por escrito; quantos e quando os que, arrastados a erros extremos pela atração de novidades, anunciaram e introduziram uma falsa ciência (1Tm 6,20), semelhantes a lobos rapaces (At 20,29) cruelmente dizimaram o rebanho de Cristo.Além disso, as tribulações sobrevindas a toda a nação judaica, logo após as insídias contra nosso Salvador [...] os ataques dos pagãos contra a palavra divina; os grandes varões [...] que por ela suportaram suplícios e combateram até o derramamento de sangue [...], e entre nós, os testemunhos prestados e a benevolência misericordiosa do Salvador para conosco - tudo isso julguei conveniente transmitir por escrito. ${ }^{18}$

${ }^{18}$ CESAREIA, Eusébio de. História Eclesiástica. São Paulo: Paulus, 2000 (I,I,I,II). 
Afirma, em seguida, que não quer outro exórdio a não ser o da realização da "economia" de Cristo. Ora, a economia se refere ao plano de Salvação que Deus tinha desde princípio dos tempos e que foi concretizada com a vinda de seu Filho a terra - o Verbo encarnado. A oikonomía, na origem grega da palavra, traduzida pelos latinos como dispensatio e administratio, aponta literalmente para a administração de Deus sobre o mundo, revelando seu caráter onisciente e onipresente ao ter ele em suas mãos o destino da humanidade e seu plano de Salvação por meio de Jesus Cristo.

Eusébio retorna às origens da humanidade para comprovar a antiguidade do cristianismo ${ }^{19}$ e fundamentar a causa da vinda de Jesus ao mundo, conforme a ideia de que o Verbo divino preexistia a tudo, ou seja, de que Pai e Filho estavam juntos desde antes do início dos tempos. A respeito da revelação do Filho como homem, o autor situa o episódio no tempo e espaço:

${ }^{19}$ O próprio Eusébio diz (I,I,VI): ...nas Crônicas que elaborei anteriormente, fiz um resumo de acontecimentos, dos quais agora me proponho dar uma descrição bem completa. O objetivo principal de tal obra (Crônica) foi o de demonstrar a antiguidade da religião cristã ligando-a a seu passado hebraico. 
No quadragésimo segundo ano do império de Augusto, no vigésimo oitavo da sujeição do Egito e da morte de Antônio e de Cleópatra, extinta a dinastia dos Ptolomeus no Egito, por ocasião do primeiro recenseamento, quando Quirino governava a Síria (Lc 2,2), nasceu nosso Senhor e Salvador Jesus Cristo, de acordo com as profecias, em Belém da Judéia (Mq 5,2). ${ }^{20}$

Tal passagem evidencia a preocupação do bispo em contextualizar e mencionar acontecimentos histórico-políticos em seus relatos. Isso é perceptível tanto quando Eusébio descreve fatos que o antecedem em aproximadamente três séculos, quanto no momento no qual fala a respeito de sua contemporaneidade romana, sob governo de Constantino. Exemplo disso são as transcrições que o autor faz de documentos imperiais: cartas redigidas pelo governante endereçadas aos bispos de Roma e de Siracusa (X,V,XVIII,XXI).

No livro décimo Eusébio discorre sobre a Paz delegada por Deus aos homens através da reconstituição e restauração de igrejas, outrora perseguidas, e da liberdade concedida aos cristãos por Constantino e Licínio no ano de 313, ainda em regime de diarquia.

[...] ordenamos que também os cristãos se conservem fiéis à própria convicção e à sua religião [...] decidimos conceder aos cristãos e a todos os outros a livre escolha de

${ }^{20}$ CESAREIA, Eusébio de. História Eclesiástica. São Paulo: Paulus, 2000. (I,V,II). 
seguir a religião que quisessem, de tal modo que tudo que possa haver de divindade e de poder celeste nos seja propício, a nós e a todos que vivem sob nossa autoridade. $^{21}$

O autor aponta, porém, que Licínio não se contentou com a posição que ocupava - "o lugar imediatamente após o grande imperador Constantino" (X,VIII,I) - e se rebelou, aliando-se ao mal e tornando-se "êmulo da perversidade e malícia dos tiranos ímpios" (X, VIII, II). Em contraposição ao dissimulador e tirano, está a figura de Constantino, com a qual Eusébio finda sua História Eclesiástica:

...sob a proteção de tal arma [piedade], nosso imperador, muito amado de Deus, escapou às conjurações deste astuto, cujo nome se tornou odioso [...] ao mesmo tempo em que decidia lutar contra Constantino, já que se dispunha a combater contra o Deus do universo, que sabia ser por ele honrado $[\ldots]^{22}$

O triunfo do imperator (e subsequente governo dos filhos) é associado ao êxito do cristianismo no relato eusebiano. $\mathrm{O}$ autor cristão vincula, portanto, a ação redentora de Jesus Cristo, o Verbo encarnado, à imagem e papel de Constantino, que é descrito por Eusébio como

${ }^{21}$ CESAREIA, Eusébio de. História Eclesiástica. São Paulo: Paulus, 2000. (X, V, II,IV).

22 CESAREIA, Eusébio de. História Eclesiástica. São Paulo: Paulus, 2000. (X,VIII,VI,VIII). 
protegido, amado e amigo de Deus, dotado de piedade e virtudes e que, como servo, fora usado para salvação geral ao ganhar os troféus da vitória sobre os ímpios.

A partir do levantamento bibliográfico realizado e das reflexões decorrentes, notamos que os autores trabalham a relação do poder político com o poder religioso sob diferentes vieses: alguns focam mais no papel de Constantino no contexto de fortalecimento do governo em consonância com a consolidação do cristianismo, como Henri Marrou e, principalmente, Paul Veyne, ao apontar tal governante como o grande responsável pela difusão do cristianismo no mundo romano do século IV, dando as bases para o predomínio desta religião até a contemporaneidade europeia. Outros autores aludem à construção de uma teologia política por Eusébio de Cesareia em relação a Constantino, enfatizando o papel da obra História Eclesiástica, como são os casos de Cristina Godoy, Josep Vilella e J.M. Blázquez.

Andréia Frazão ${ }^{23}$ menciona que Eusébio legitimou o novo status da Ecclesia através das profecias que se cumpriam, e que para o autor o Império se transformou em uma entidade político-religiosa detentora da

\footnotetext{
${ }^{23}$ FRAZÃO, A.C.L. Reflexões Sobre os Martírios, a Obra História Eclesiástica de Eusébio de Cesaréia e a Hagiografia Cristã. In: Ciclo de debates em História Antiga. 18. Rio de Janeiro, 2008. Dialogando com Clio. Anais Eletrônicos do XVIII Ciclo de Debates em História Antiga. Rio de Janeiro: Lhia, 2008. p. 1-26.
} 
missão de levar a fé sob a figura de um único líder. Com a História Eclesiástica, o bispo pretendeu demonstrar que, mesmo enfrentando muitos problemas como as perseguições e heresias, a Igreja do século IV, reconhecida pelo Império, manteve-se fiel à mensagem revelada por Cristo.

Em Renan Frighetto, Gilvan V. da Silva e Norma Mendes, há a ênfase na continuidade do paganismo em relação ao cristianismo, tanto a nível da elaboração mesma das ideias cristãs, quanto da interação desta religião com o poder político-institucional. É neste âmbito que entra, a título de (bom) exemplo, o conceito de uma basileia sagrada (realeza helenístico-cristã), mencionada por Gilvan e Norma; de "origens orientais" gregas e persas, características dessa forma de governo são introjetadas gradativamente no poder político romano, através também do papel de teóricos e eruditos do período.

Arnaldo Momigliano é outro autor que trabalha na perspectiva citada - de interação e continuidade entre os pensamentos pagão e cristão. Além disso, inclina-se para a ideia da formulação de uma nação cristã em Eusébio de Cesareia: "mesmo ansioso em preservar a herança cultural pagã da nova ordem cristã [...] Eusébio sabia que os cristãos eram uma nação, e uma nação vitoriosa; e que sua história não podia 
ser contada a não ser no quadro da igreja em que vivia". ${ }^{24}$ A respeito da nação cristã e da própria escrita da História Eclesiástica pelo bispo palestino, Momigliano afirma que Eusébio não conseguiu separar o que pertencia a César e o que pertencia a Cristo, já que a narrativa comportava uma dualidade: "de um lado a história eclesiástica era a história da nação cristã agora emergindo como a classe dominante do Império Romano. Por outro lado, era a história da instituição divina não contaminada por problemas políticos". 25

A nosso ver, acordamos com a perspectiva de fortalecimento tanto da Igreja cristã quanto da instituição imperial, centrada naquele momento em Constantino, conforme o caráter de interelação entre política e religião. Difícil é delimitar até que ponto dava-se essa interação; talvez por isso mesmo que haja distintas e variadas interpretações a respeito de um século marcado por permanências, transformações e readequações políticas, sociais e religiosas.

${ }^{24}$ MOMIGLIANO, Arnaldo. As origens da historiografia eclesiástica, in: As raízes clássicas da historiografia moderna. Bauru: Edusc, 2004, p.196.

${ }^{25}$ Ibid, p. 199. 


\section{CONCLUSÕES PARCIAIS}

Ao refletir a respeito das questões expostas no atual trabalho, vêm-nos à mente de maneira imediata a negação de qualquer noção de imobilidade no mundo romano do século IV, em particular de suas primeiras décadas. Tal asserção é percebida pelo caráter dinâmico de elementos como o poder político e a religião, que, uma vez imbricados sem esquecer-nos dos aspectos sociais, culturais, entre outros dificultam e até mesmo impossibilitam a pretensa ideia de enquadrar e determinar as causas e efeitos de acontecimentos, como o que aqui nos ocupa: a legitimidade de poder.

Mesmo sujeitas a refutações, é a partir do conhecimento contextual e da análise de fonte, que acreditamos serem nossas ideias dignas à colaboração interpretativa no que tange ao governo de Constantino, e sua fundamentação ideológica através de preceitos cristãos. Evidente está que o cristianismo, na obra de Eusébio de Cesareia, participou ativamente na formatação do caráter do poder imperial centrado na figura constantiniana. Da mesma forma, percebemos a 'ascensão' desta crença ao ser vinculada à política institucional romana. $\mathrm{O}$ que não devemos negligenciar, de nenhuma maneira, é a complexidade intelecto-cultural do espaço romano, em 
contato constante com ideias e tradições provenientes de outras espacialidades.

A História Eclesiástica de Eusébio é um sintoma explícito do perfil de interação e diálogo entre elementos diversos - cristianismo, paganismo, religião hebraica, etc. - e sua relação mútua com o poder político. Assim como Arnaldo Momigliano defende que na obra do bispo palestino é impossível separar o que pertence a César e o que pertence a Cristo, cremos na inviabilidade de distinguir o caráter político do caráter religioso de Eusébio de Cesareia. O erudito possui a intenção de comprovar a antiguidade e veracidade do cristianismo, ao mesmo tempo em que justifica e reveste de virtudes o poder imperial.

Entre os vários objetivos que Eusébio de Cesareia teria para escrever uma história eclesiástica imerso em um ambiente de diálogos e tensões entre 'cristianismos' e 'paganismos', além das próprias dissensões internas ao cristianismo, um de altíssima relevância é, a nosso ver, a busca por legitimidade dessa crença não apenas como uma religião, em meio a várias outras, mas à sua afirmação como religião triunfante. Nesse ínterim, o apoio do poder imperial romano é salutar para o processo de consolidação da mesma, processo esse que teve impulsos já com Eusébio sob o governo de Constantino. 
Revista Vernáculo, $n^{\circ} 28,2^{\circ}$ sem/2011

No contexto de desestruturação político-institucional do cenário romano, ao qual nos referimos ao longo desse artigo, acreditamos ser um elemento essencial a busca por unidade, tanto política quanto religiosa. Essa preocupação é um dos principais aspectos que move a escrita da História Eclesiástica por Eusébio de Cesareia. 


\section{REFERÊNCIAS BIBLIOGRÁFICAS}

\section{Fonte}

CESAREA, Eusebio di. Storia Ecclesiastica. Roma: Città Nuova Editrice, 2005.

CESAREIA, Eusébio de. História Eclesiástica. São Paulo: Paulus, 2000 .

EUSEBIUS. Ecclesiastical History. Harvard University Press, 1926.

\section{Bibliografia}

ALTANER, B; STUIBER, A. Patrologia: vida, obras e doutrina dos Padres da Igreja. São Paulo: Paulinas, 1988.

CURTI, C. Eusébio de Cesareia, in: Dicionário Patrístico e de Antiguidades cristãs. Petrópolis: Vozes, 2002.

DANIÉlOU, Jean e MARROU, Henri. Nova História da Igreja. Petrópolis: Vozes, 1973, v.I.

FRAZÃO, Andréia Cristina Lopes. O nascimento da Historiografia cristã no IV século. Calíope. Presença Clássica, Rio de Janeiro, n. 9, p. 83-92, 1993. 
Revista Vernáculo, $n^{\circ} 28,2^{\circ}$ sem/2011

, Andréia Cristina Lopes. Reflexões Sobre os Martírios, a

Obra História Eclesiástica de Eusébio de Cesaréia e a Hagiografia Cristã, in: CICLO DE DEBATES EM HISTÓRIA ANTIGA. 18. Rio de Janeiro, 2008. Dialogando com Clio. Anais Eletrônicos do XVIII Ciclo de Debates em História Antiga. Rio de Janeiro: Lhia, 2008. p. 126.

GODOY, C.; VILELLA, J. De la fides ghotica a la ortodoxia nicena: inicio de la teologia política visigótica, in: Antigüedad y Cristianismo - Monografias históricas sobre la Antigüedad Tardia. Murcia: 1986.

GURRUCHAGA, Martín. Introducción, in: Eusebio de Cesarea. Vida de Constantino. Madrid: Editorial Gredos, 1994.

FRIGHETTO, Renan. A longa Antiguidade Tardia: problemas e possibilidades de um conceito historiográfico, In: Programa de Estudos Medievais. (Atas da VII Semana de Estudos Medievais). Brasília: UNB, 2009.

Renan. Algunas consideraciones sobre las construcciones teóricas de la centralización del poder político en la Antigüedad Tardia: cristianismo, tradición y poder imperial, In: 
Revista Vernáculo, $n^{\circ} 28,2^{\circ}$ sem/2011

História: Entre el pesimismo y la esperanza. Viñadel Mar: Altazor, 2007.

HORNBLOWER, S; SPAWFORTH, T. (eds.) Diccionario del mundo clásico. Barcelona: Crítica, 2002.

MAZA, Clelia Martínez, ALVAR, Jaime. Cultos mistéricos y cristianismo, In: Cristianismo primitivo y religiones mistéricas. Madrid: Cátedra, 2007, p.515-536.

MOMIGLIANO, Arnaldo. As origens da historiografia eclesiástica. In: As raízes clássicas da historiografia moderna. Bauru: Edusc, 2004.

PATRICH, Joseph. Caesarea in the Time of Eusebius. In: Reconsidering Eusebius, Collected Papers on Literary, Historical, and Theological Issues. Inowlocki, S e Zamagni, C. (ed.). Boston: Brill, 2011.

SILVA, Gilvan Ventura da; MARVILA, M. De Laudibus

Constantini: o discurso de Eusébio de Cesareia sobre a realeza. ES:

Dimensões, 2006.

, Gilvan Ventura da; MENDES, Norma Musco. Diocleciano e Constantino: a construção do DOMINATO, in: Repensando o Império 
Revista Vernáculo, $n^{\circ} 28,2^{\circ}$ sem/2011

Romano - Perspectiva socioeconômica, política e cultural. Vitória:

Edufes, 2006.

VEYNE, Paul. Quando o nosso mundo se tornou cristão. Lisboa:

Edições Texto \& Grafia, 2007.

WINKELMANN, Friedhelm. "Historiography in the age of Constantine", in Greek and Roman historiography in Late Antiquity, G. Marasco (ed.). Boston: Brill, 2003. 